\title{
MINERAL INCLUSIONS IN MICRODIAMONDS AND MACRODIAMONDS FROM KIMBERLITES OF YAKUTIA: A COMPARATIVE STUDY
}

\author{
Nikolai V. Sobolev, Alla M. Logvinova, Dmitry A. Zedgenizov and Emiliya S. Yefimova, \\ Institute of Mineralogy and Petrography, Russian Academy of Sciences, Siberian Branch, Novosibirsk, Russia
}

\section{INTRODUCTION}

Microdiamonds $(<1 \mathrm{~mm})$ exhibit a wide range of physical characteristics which may suggest about availability of different microdiamond populations at each location (Pattison, Levinson, 1995; Trautman et al., 1997). In spite of their size, microdiamonds contain mineral inclusions of comparable size with those of macrodiamonds $(>1 \mathrm{~mm})$. Recent investigations of mineral inclusions from a limited number of Yakutian microdiamonds have brought new results compared with inclusions from macrodiamonds of the same pipes (Logvinova et al., 2001, Sobolev et al., 2000, 2001, Zedgenizov et al., 1998, 2001). Several hundreds of microdiamonds $(<1 \mathrm{~mm})$ from eight diamondiferous kimberlite pipes, of Yakutia including all presently operated diamond mines (Mir, Internationalnaya, Udachnaya, Aykhal, Sytykanskaya, Yubileynaya, Komsomolskaya pipes) were found to contain mineral inclusions, which were analyzed by electron microprobe technique. Their compositions are compared with compositions of mineral inclusions studied from about 2000 macrodiamonds (>1 mm) from the same pipes. Data of inclusions composition from macrodiamonds are mainly collected from authors data base, consisting of published results and unpublished data by the authors.

\section{ANALYTICAL METHODS}

Micro-Raman spectroscopy has been used for nondestructive inclusion identification. Mineral inclusions were released from diamonds both by crushing and burning as well as by polishing host diamonds until inclusions were exposed. Inclusion grains, as well as polished fragments of diamonds with exposed inclusions, were mounted on epoxy resin and polished for analysis. Major elements were analyzed with a CAMEBAX electron microprobe at Novosibirsk. The analyses were performed at $15 \mathrm{kV}$, with a $20 \mathrm{nA}$ beam current, and a 1-5 $\mu \mathrm{m}$ spot size. Counting times varied from $20 \mathrm{~s}$ for major elements to $100 \mathrm{~s}$ for trace components.. All analyses EMP data were fully corrected by the Cameca PAP ( ZAF) software.

\section{MINERAL INCLUSIONS}

Olivine is the most abundant mineral inclusion in Yakutian diamonds (Yefimova, Sobolev, 1977). The available data base of olivine compositions from macrodiamonds worldwide summarized by Meyer (1987) and Sobolev et al. (2000) presents the information on $\mathrm{NiO}$ (wt.\%) and $\mathrm{Fo}=100 \mathrm{Mg} /(\mathrm{Mg}+\mathrm{Fe})$. The highest number of data plots falls in the range of Fo - 92-93 and $\mathrm{NiO}=0.30-0.38$ wt.\%. However, olivines from microdiamonds of Yubileynaya mine demonstrated surprising exceptions with several samples containing $\mathrm{Fo}-86-89$ and $\mathrm{NiO}=0.46-0.64$ wt.\% These extreme compositions represented about $20 \%$ of all studied olivines from Yubileynaya microdiamonds. However, Udachnaya microdiamond olivines were of a traditional composition.

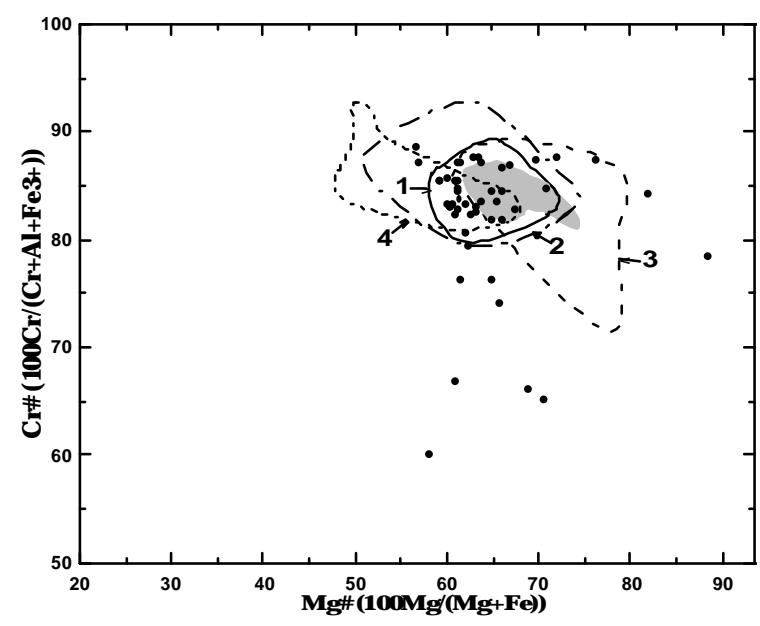

Figure 1: Cr\# vs Mg\# plot for chromites coexisting with diamonds from kimberlites of Yakutia $(1,2)$, South Africa (3), from polycrystalline diamond aggregates (PDA) of Yakutia and South Africa. Shaded field: compositional variations of 34 chromite grains extracted from a single diamond, Udachnaya pipe, UD-34. Solid circles - chromites from Yakutian microdiamonds.

Chromite as one of very typical inclusion in Yakutian diamonds is also of a great interest for such a comparative study. Forty nine chromite samples from microdiamonds of Udachnaya, Aykhal and 
Yubileynaya pipes have been analyzed. The results are plotted in Fig.1. The expanded compositional field of chromites from Yakutian diamonds (field 2 in Fig.1) is based upon 700 plots and $10 \%$ only of chromites from macrodiamonds plot out of this field (Sobolev et al., 1975, 1989, 1997).

The first attempt to study chromite inclusions from microdiamonds have demonstrated extreme variations of their compositions. $75 \%$ of all analyzed chromites plot within expanded field of chromite compositions from Yakutian diamonds. This field includes a summary of analytical data of 34 chromite grains from Ud-34 (Udachnaya macrodiamond). This summary is plotted as shaded area (Sobolev et al., 1989). 25\% of analyses of chromites from microdiamonds plot very far away from the major field. Compositions of some chromites are extremely Mg-rich with $\mathrm{Mg \#}$ exceeding 85 .

Cr-pyropes are considerably more rare inclusions both in macro- and microdiamonds compared with olivines and chromites. Along with a general similarity of Crrich garnets composition in both diamond types a unique $\mathrm{Cr}$-Ca-rich majoritic garnet was discovered in a microdiamond of Yubileynaya pipe. It coexists with Cr$\mathrm{Ca}$ rich non-majoritic garnet and olivine within the same diamond (Sobolev et al., 2002). Positive identification of majoritic garnet was preliminary obtained by single-crystal X-ray diffraction. The specific features of the compositions of coexisting majoritic and non-majoritic garnets, respectively: $\mathrm{Si}$ $(\mathrm{pfu})=3.29 \& 3.02 ; \mathrm{Cr} 2 \mathrm{O} 3(\mathrm{wt} . \%)=10.2$ and 13.7; $\mathrm{CaO}($ wt.\%) $=20.8$ and 12.7; $\mathrm{Mg \#} 77.6$ and 69.9. Coexisting olivine is Fo 91.5, which is consistent with the relatively low $\mathrm{Mg \#}$ of the majoritic garnet. Furthermore, garnets $\mathrm{CaCr}$-component (uvarovite) content of majoritic garnet is unusually high (more than $50 \%)$.

E-type garnets from microdiamonds. Compositions of some of E-type garnets are plotted outside the typical range of $\mathrm{Mg}-\mathrm{Ca}-\mathrm{Fe}$ contents, containing up to $50 \% \mathrm{Ca}-$ component along with high $\mathrm{Mg} \# 70$ and $30 \%$ of Cacomponent along with very low Mg\# 30. Two E-type majoritic garnets with the range of $\mathrm{Si}$ (pfu) from 3.05 to 3.13 and high $\mathrm{Na} 2 \mathrm{O}$ contents (up to $0.93 \mathrm{wt} \%$ ) are discovered in microdiamonds. In both garnets $\mathrm{Na}$ exceeds Ti (pfu), respectively, 0.28 and 0.39 Sobolev, Lavrent'ev, 1971). They are similar to some garnets from Monastery pipe (Moore, Gurney, 1985).

\section{DISCUSSION AND CONCLUSIONS}

Olivines, chromites, U-type and E-type garnets have been studied from microdiamonds for comparative purpose with similar minerals from macrodiamonds of Yakutian mines. At present time the data base of inclusion compositions from Yakutian macrodiamonds is almost an order of magnitude larger compared with that from microdiamonds. However, important differences in compositions of all listed minerals were well established. These differences include: 1) The discovery of anomalously high $\mathrm{NiO}(0.45-0.64 \mathrm{wt} . \%)$ in low Fo $(<90)$ olivines from Yubileinaya pipe (Sobolev, et al., 2000); 2) Finding of anomalously magnesian (Mg\# >80) and Ti-rich (> 4wt.\% TiO2) chromites; 3) The discovery of $\mathrm{Cr}$-Ca-rich majoritic garnet in a microdiamond from Yubileynaya pipe) (Sobolev et al., 2002); 4) The discovery of majoritic E-type garnets (Sobolev et al., 2002); 5) The discovery of ferropericlase inclusion (Zedgenizov et al., 2001). We conclude that mineral inclusions in macrodiamonds are more variable in their compositions compared with inclusions in macrodiamonds. Majoritic garnets are found both in U-type and E-type microdiamonds but not in macrodiamonds. These features may be related to the specific composition and probably, deeper origin (more than $300 \mathrm{~km}$ ) of a part $(10-20 \%$ in different pipes) of microdiamonds source.

\section{REFERENCES}

Griffin, W.L., Ryan, C.G., Gurney, J.J., Sobolev, N.V., 1994. Chromite macrocrysts in kimberlites and lamproites: geochemistry and origin. In: Meyer, H.O.A., Leonardos, O.H. (Eds.). Kimberlites, related rocks and mantle xenoliths. CPRM Spec. Publ. 1A/93, pp. 366377.

Logvinova, A.M., Zedgenizov, D.A., Sobolev, N.V., 2001. Pyroxenite paragenesis of abundant mineral and probable fluid inclusions in microdiamons from the Mir kimberlite pipe, Yakutia. Dokl. Acad. Nauk 380, 363-367 (in Russian). English Translation: Dokl. Earth Sci. 380, 795-799.

Meyer. H.O.A. 1987. Inclusions in diamonds. In: Nixon. P.H. (Ed.). Mantle xenoliths. Chichester, England. John Wiley and Sons. pp. 501-522.

Moore, R.O., Gurney, J.J., 1985. Pyroxene solid solution in garnets included in diamond. Nature 318, 583.

Pattison, D.R.M., Levinson, A.A., 1995. Are euhedral microdiamonds formed during ascent and decompression of kimberlite magma? Implications for use of microdiamond in diamond grade estimation. Applied Geochim. 10, 725-740.

Sobolev, N.V. 1974. Deep-seated inclusions in kimberlites and the problem of the composition of the Upper mantle. Novosibirsk, Nauka Publ. House (in Russian). 
English Translation: 1977, Boyd, F.R. (Ed.), Washington. D.C.. American Geological Union.

Sobolev, N.V., Lavrent'ev, Y.G., 1971. Isomorphic sodium admixture in garnets formed at high pressures. Contrib. Mineral. Petrol. 31, 1-12.

Sobolev, NV., Logvinova, A.M., Zedgenizov, D.A., Yefimova, E.S., Lavrent'ev, Yu.G., Usova, L.V., 2000. Anomalously high $\mathrm{Ni}$ admixture in olivine inclusions from microdiamonds, the Yubileynaya kimberlite pipe, Yakutia. Dokl. Akad. Nauk 375, 393396 (in Russian). English Translation: Dokl. Earth Sci. 375A, 1403-1406.

Sobolev, N,V., Taylor, L.A., Logvinova, A.M., Seryotkin, Y.V., Koptil, V.I., Yefimova, E.S., 2002. First report of majoritic garnet diamond inclusions from Yakutian kimberlites. AGU Fall Meeting, San Francisco, F1403.

Sobolev, N.V., Yefimova, E.S., Logvinova, A.M., Sukhodolskaya, O.V., Solodova, Yu.P., 2001, Abundance and composition of mineral inclusions in large diamonds from Yakutia. Dokl. Akad. Nauk 376, 382-386 (in Russian). English Translation: Dokl. Earth Sci. 376, 34-38.

Sobolev, N.V., Yefimova, E.S., Reimers, L.F., Zakharchenko, O.D., Makhin, A.I., Usova, L.V., 1997. Mineral inclusions in diamonds of the Arkhangelsk kimberlite province. Russian Geol. Geophys. 38, 379-393.

Trautman, R.L., Griffin, B.J., Taylor, L.A., Spetsius, Z.V., Smith, C.B., Lee, D.C., 1997. A comparison of the microdiamonds from kimberlite and lamproite of Yakutia and Australia. Russian Geol. Geophys. 38, 341-355.

Yefimova, E.S., Sobolev, N.V., 1977. Abundance of crystalline inclusions in Yakutian diamonds. Dokl. Akad. Nauk SSSR 237, 1475-1478 (in Russian).

Zedgenizov, D.A., Logvinova, A.M., Shatskii, V.S., Sobolev, N.V., 1998. Inclusions in microdiamonds from some kimberlite diatremes of Yakutia. Dokl. Earth Sci. 359, 204-208.

Zedgenizov, D.A., Yefimova, E.S., Logvinova, A.M., Shatsky, V.S., Sobolev, N.V., 2001. Ferropericlase inclusions in a diamond microcrystal from Udachnaya kimberlite pipe, Yakutia. Dokl. Akad. Nauk 377, 381384 (in Russian). English Translation: Dokl. Earth Sci. 377A, 319-321.

Contact: N.V.Sobolev, Institute Mineralogy and Petrography, Novosibirsk, 630090, Koptyug ave., 3, Russia. E-mail:

sobolev@uiggm.nsc.ru 